\title{
Impact of risk management strategies on the credit risk faced by commercial banks of Balochistan
}

\author{
Zia Ur Rehman, Noor Muhammad*, Bilal Sarwar and Muhammad Asif Raz
}

\author{
* Correspondence: uighor@yahoo. \\ com \\ Balochistan University of \\ Information Technology \\ Engineering \& Management \\ Sciences, Quetta, Pakistan
}

\begin{abstract}
This study aims to identify risk management strategies undertaken by the commercial banks of Balochistan, Pakistan, to mitigate or eliminate credit risk. The findings of the study are significant as commercial banks will understand the effectiveness of various risk management strategies and may apply them for minimizing credit risk. This explanatory study analyses the opinions of the employees of selected commercial banks about which strategies are useful for mitigating credit risk. Quantitative data was collected from 250 employees of commercial banks to perform multiple regression analyses, which were used for the analysis. The results identified four areas of impact on credit risk management (CRM): corporate governance exerts the greatest impact, followed by diversification, which plays a significant role, hedging and, finally, the bank's Capital Adequacy Ratio. This study highlights these four risk management strategies, which are critical for commercial banks to resolve their credit risk.

Keywords: Credit risk, Risk management strategies, Financial risk, Capital adequacy ratio, Hedging, Corporate governance, Diversification
\end{abstract}

\section{Introduction}

Credit risk causes economic downturn as banks fail due to default risk from clients, which has had a negative impact on the economic development of many nations around the world (Reinhart \& Rogoff, 2008). By definition, credit risk describes the risk of default by a borrower who fails to repay the money borrowed. The term hedging signals the protection of a business's investments by limiting its level of risk, for example, by purchasing an insurance policy. Diversification is the allocation of financial resources in variety of different investments and has also long been understood to minimize such risk. The capital adequacy ratio is a measure of a bank's capital maintained to absorb its outlying risks. Since there is a lot of competition among banks to attract customers, therefore, it has triggered several innovations in banking services (Aruwa \& Musa, 2014). Regulators also require banks to improve internal governance practices in order to ensure transparency and ethical standards to keep the customers satisfied with their products and services. Ambiguity in banks' terms and conditions will make it difficult for customers to select financial products appropriate for their needs, whereas clear terms and conditions allow customers to be more satisfied with the bank's performance (Ho \& Yusoff, 2009). Customers expect the financial

(c) The Author(s). 2019 Open Access This article is distributed under the terms of the Creative Commons Attribution 4.0 International License (http://creativecommons.org/licenses/by/4.0/), which permits unrestricted use, distribution, and reproduction in any medium, provided you give appropriate credit to the original author(s) and the source, provide a link to the Creative Commons license, and indicate if changes were made. 
institutions to have strong policies that can safeguard their interests and protect them. Therefore, poor understanding of effective credit risk and the acceptable risk management strategies by bank managers poses a threat to the commercial banks advancement and customers' interest.

One critical success factor for financial institutions lies in their realization of the importance of credit risk and devising solid strategies - such as hedging, diversification and managing their capital adequacy ratio - to avoid shortcomings that could lead to operational catastrophe. Credit risks faced by banks have fundamental impact on the performance because, even few large customers default on loans would cause huge problems for it. The objective of the Credit Risk Management (CRM) process is to maximize the cost-adjusted rate of return of a particular bank by maintaining exposure to credit risk acceptable to its shareholders. Banks have to navigate the credit risk associated with the overall portfolio as well as external risks that may be due to macroeconomic factors in the economy. Banks must also compare the credit risk relationships with other risks. Another specific case of credit risk applies to the method of trying to settle banking transactions. Until and unless both parties settle their payments in a timely manner, bank suffers from opportunity loss. Corporate governance may also have large effect on the risk management strategies used by the bank for reducing credit risks. Research suggests that it is imperative that banks engage in prior planning in order to avoid future problems (Andrews, 1980).

Majority of commercial banks provide several services that could help them mitigate or manage risk. For example, hedging has been used to reduce the level of risk involved in transactions by keeping specific conditions that would allow different parties to exchange goods or services at a flexible date and time (Harrison \& Pliska, 1981). The significance of effective risk management strategies have been highlighted by many researchers and practitioners over time to assist banks and other financial institutions. CRM became an obvious necessity for commercial banks, especially after the 2008 global financial crisis, in which it was primarily subprime mortgages that caused a liquidity crisis (Al-Tamimi, 2008). According to Al-Tamimi (2008), ensuring the efficient practice of risk management may not be expensive but the implementation should be done in a timely manner in order to ensure smooth banking operations.

A financial institution, just like a constituent part of any other major economic sector, aims to meet incurred expenses, increase the return on invested capital and maximize the wealth of its shareholders. In their pursuance of these objectives, the financial system has to offer effective risk management strategies to financial institutions like banks against credit risk (Hakim \& Neaime, 2005).

\section{Problem statement}

In 2008, across the world, the credit crisis began as a result of mass issuing of subprime mortgages to individuals in the United States leading to defaults, which caused outwardly-rippling problems for financial institutions all across the world. Sub-prime mortgages and other loans with less restrictions can generate remarkable losses including corporate failure and bankruptcy for financial institution (Brown \& Moles, 2014). These credit decisions have a pivotal role in firms' profitability. The decision to overextend credit to high-risk customers may increase short-term profitability for individual banks, though in aggregate, this lending behavior was seen to become a major challenge 
to the risk management structures of the economy as a whole. Therefore, managing risk is the most important element of a bank's operations. This phenomenon is equally applicable to banks across the globe, including banks in Pakistan.

Due to unstable and volatile nature of the political and financial environment in Pakistan, banks are affected by many types of risk, including risks to foreign exchange rates, liquidity, operations, credit and interest rates. Pakistan's financial institutions are generally risk-averse, especially towards car financing and mortgage loans in which chances of huge losses are higher (Shafiq \& Nasr, 2010). Balochistan is the least developed part with largest geographical area in Pakistan. There are limited opportunities for small businesses and majority of businesses are run in informal form with poor documentation. Majority of commercial banks face problems like loan documents verification and loan processing. Therefore, the adoption of proper risk management strategies can help understand and mitigate the credit risk faced by commercial banks of Balochistan.

\section{Research objective}

This study aims to identify the different risk management strategies that can influence the management of credit risk by commercial banks. We expect to determine if these strategies contribute both to the reduction of credit risk as well as the efficient performance in fulfilling customer needs.

\section{Significance of the study}

This study aims to provide a basis for guidance for the commercial banks of Balochistan to adopt long-term performance-improving risk management strategies (Campbell, 2007). The model for the study shows the impact of risk management strategies, including hedging, diversification, the capital adequacy ratio and corporate governance. The research will also examine the impact of each risk management strategy individually in order to understand the importance of each strategy. To the best of authors' knowledge, there is no study on credit risk management on Balochistan using the described parameters. The findings of this study are intended to contribute positively to society by demonstrating that the banks of Balochistan can develop effective strategies to improve their CRM. Additionally, policy makers can identify and generate appropriate policies to govern bank behavior in order to minimize risk.

\section{Literature review}

Credit risk is considered as the chance of loss that will occur when the loan or any other line of credit by a particular debtor is not repaid (Campbell, 2007). Since 2008, financial experts around the world have researched and analyzed the primary factors underpinning the credit crisis to identify problematic behavior and effective solutions that can help financial institutions avoid catastrophe in the future. Long ago, the Basel Committee on Banking Supervision ${ }^{1}$ (1999) has also identified credit risk as potential threat to banking sector and developed certain banking regulations that must be maintained by the banks around the world. Owojori, Akintoye, and Adidu (2011) stated that

${ }^{1}$ This is a place in Switzerland where the Basel Committee on Banking Supervision (BCBS) comprising of 45 members from 28 Jurisdictions, consisting of Central Banks and authorities have the responsibility of banking regulation. 
there are legislative inadequacies in financial system especially in banking system that are effective as well as lack of uniform credit information sharing amongst banks. Thus, it urges to the fact that banks need to emphasize on better risk management strategies which may protect them in the long run.

Abiola and Olausi (2014) emphasized on the establishment of a separate credit unit at banks with professional staff for credit/loan officers and field officers. It is important as they perform variety of functions from project appraisals through credit disbursement, loan monitoring to loans collection. Therefore, a comprehensive human resource policy related their selection, training, placement, job evaluation, discipline, and remuneration need to be in placed to avoid any inefficiencies related to loan management and credit defaults.

Ho and Yusoff (2009) focused on researching Malaysian financial institutions and their management of credit risk. The study involved a sample of 15 foreign and domestic financial institutions from which the data was collected through questionnaires. The findings demonstrated that the diversification of loan services leads to risk improvement, though it requires training employees and the commitment of employees to ensure that the financial institution will meet the requirements for best practice lending.

Brown and Wang (2002) conducted study about the challenges faced by Australian financial institutions due to credit risk over the period January 1986 to August 1993. The Australian financial institutions were not able to provide a wide variety of alternatives to their clients that led to higher risks as there was a lack of diversification in their services. The research suggested that corporate governance practices allow firms to adopt appropriate rules, policies, and procedures to ensure that the rights of all the stakeholders are fulfilled. Hedging ${ }^{2}$ is used by financial institutions to minimize the risk associated with the transactions conducted with the bank customers as it allows the bank to minimize the risk by offering flexible offers that allows customer to make their decisions effectively (Dupire, 1992).

The work of Karoui and Huang (1997) indicates that the super hedging strategy ${ }^{3}$ could be implemented to achieve a surplus downside market risk as it possesses a duality of both the super hedging and open hedging approaches. The prices of options can increase due to the volatility of the asset prices. If the prices of the financial instrument are fluctuating, then the price of the options contract might also be influenced as the buyers or sellers will be deriving their profit from the price of the financial security (Hobson, 1998).

Several factors are associated with the pricing of securities as these factors support the financial decisions that must be made by the investors. The loans that the bank provides to the borrower are highly dependent on the conditions of the market. Decision-making for mitigation and management of credit risk is very important for banks (Li, Kou, \& Peng, 2016). A highly volatile security market will influence the prices and interest rates of the securities being exchanged in such a market. Financial markets are affected by the macroeconomic variables that influence the prices of the securities being exchanged. Hedging allows firms and their managers to incorporate

\footnotetext{
${ }^{2}$ Hedging are flexible contracts that allow customers to agree to buy a particular product in future date using spot rates. It allows customers and banks to manage the transaction by locking contracts at desired price. ${ }^{3}$ Super hedging strategy allows the users to hedge their positions with a trading plan based on self-financing. A low price is paid for the portfolio that would ensure that it's worth to be equal or higher at a future date.
} 
policies that will maximize the value of the company as clients have a wide array of alternatives that allow them to make their decisions in an effective manner. The derivatives such as options, futures, forwards and swaps that are used by firms increase their financial stability by allowing the customers to have sufficient information that improves their decision making in different circumstances. This enables managers to adopt practices that will benefit their organizations. Hedging allows businesses to support a higher debt load due to its flexible nature and ability to minimize risk, which increases the value of the company as it can actually meet the needs of more customers with a comparatively lower level of risk (Graham \& Rogers, 2002). Similarly, Levitt (2004) explained that hedging enables firms to extend its activities because the risk inherent to providing funds is reduced in such transactions, allowing more flexibility to all involved parties.

Banks are able to maintain a particular level of reserved cash for the sake of managing the day to day operations that is decided based on the allocated capital adequacy ratio. This enables the bank to maintain a balance of cash that is sufficient to meet the needs of the customers. Managers can use the bank's available cash flow to meet short-term cash requirement needs, which are based on the concept of capital adequacy ratio. This gives certainty to some funds that banks must maintain in order to address unforeseen circumstances. The selective hedging concept has been used by firms for the sake of making investments that are based on a certain part of their portfolio that pose the most threat and not the entire portfolio of the financial instruments (Stulz, 1996). The emphasis is on utilizing hedging at the right time for the specific customer that a company believes should be entering into a contract with flexible terms and conditions. It is a viable option for banks to use hedging to avoid customers' dissatisfaction for those who do not meet the firm's loan eligibility criteria. Zhang, Kou \& Peng, (2019) proposed a consensus model that considers the cost and degree of consensus in the group decision making process. With a certain degree of consensus the generalized soft cost consensus model was developed by defining the generalized aggregation operator and consensus level function. The cost is properly reviewed from the perspective of the individual experts and the moderator. Economic significance of the two soft consensus cost models is also assessed. The usability of the model for the real-world context is checked by applying it to a loan consensus scenario that is based on online data from a lending platform. Group decision making is critical for changing the opinions of everyone to arrive at a synchronized strategy for minimizing the risks of the bank with the help of hedging (Zhang, Kou, \& Peng, 2019).

Kou, Chao, Peng, Alsaadi \& Herrera-Viedma, (2019) identified that financial systemic risk is a major issue in financial systems and economics. Machine learning methods are employed by researchers that are trying to respond to systemic risks with the help of financial market data. Machine learning methods are used for understanding the outbreak and contagion of the systemic risk for improving the current regulations of the financial market and industry. The paper studies the research and methodologies on measurement of financial systemic risk with the help of big data analysis, sentiment analysis and network analysis. Machine learning methods are used along with systematic financial risk management for controlling the overall risks faced by the banks that are related to hedging of the financial instruments of the bank (Kou, Chao, Peng, Alsaadi, \& Herrera-Viedma, 2019). 
Provision of financial assistance to customers that require the funds for business activity can prove profitable for the bank (Datta, Rajagopalan, \& Rasheed, 1991). If the principle and interest of the loan is repaid in a timely manner that would help the banks ensure smooth flow of their operations, and the economic activities in the society are improved as the standard of living of people also improves with such financial assistance that is provided by commercial banks (Keats, 1990). As banks enter into such contracts with several customers, the level of the its incurred risk increases; management likewise becomes more complex with a more diverse group of customers (Kargi, 2011). Non-Performing Loans (NPL) represent the credit that a bank believes is causing a loss, and includes loan defaults, which are typically categorized by their expectation of recovery as "standard," "doubtful" or "lost" (Kolapo, Ayeni, \& Oke, 2012). The lost category focusing on the inability of the bank to recover particular products restricts a bank from reaching the set targets thus causing a bank to fail in attaining the objectives of profitability that have been set. The incurrence of a large amount of high-risk debt is often difficult for banks to manage unless the managers have undertaken appropriate strategies for mitigating the risk in addition to enhancing their financial performance. The existence of NPLs prompted central global banks to enter into the 1988 Basel Accord, also known as Basel I (later superseded in 2004 by Basel II), which maintained that banks must maintain a particular amount of capital in order to meet their operational needs (Van Greuning \& Brajovic Bratanovic, 2009). This on-hand capital requirement, also called the capital adequacy ratio, is beneficial as it allows banks to more easily manage potential, sudden financial losses (Keats, 1990).

Kithinji (2010) provides specific evidence that the management of credit risk does not influence the profitability of banks in Kenya. In fact, the Kargi (2011) study on Nigerian banks from 2004 to 2008 revealed a healthy relationship between appropriate CRM (Credit Risk Management) and bank performance. Poudel (2012) emphasized the significant role played by CRM in the improvement of financial performance of banks in Nepal between 2001 and 2011. Strict requirements of maintaining higher capital that is around $14.3 \%$ of the cash balance as reserve in the banks of Nepal was found to have resulted in better bank performance by producing more profit.

Heffernan (1996) stated that CRM is crucial for predicting proper bank financial performance. A bank's inability to recoup its outstanding loans reduces its ability to engage in other profitable transactions A loss both of principle as well as interest (including time value) means also a loss in opportunities to expand and pursue other profitable operations (Berríos, 2013).

Banks that avoid risk management face several challenges, including their own survival in the current highly competitive financial environment. To compete successfully with other commercial financial institutions, banks rely on a diversification of products and financial services to improve portfolio performance, including attracting more customers. Diversified services allow customers to select the most appropriate financial assistance in light of their individual needs. Along with diversification of the financial services, banks need to manage the credit risk involved where funds are given as loans for various needs of the customers such as car loans, house loans, starting a new business or expanding ongoing business (Kou, Ergu, Lin, \& Chen, 2016). It is also important to have effective behavior monitoring models to ensure that bank employees are careful in minimizing the operational risks by providing maximum information to the 
customers about the financial instruments and the restrictions imposed by the bank for the sake of protecting the interests of the financial institution. Chao, Kou, Peng \& Alsaadi, (2019) conducted a study to understand a new form of money laundering that is trade based which is using the signboard of international trade. It appears along with the capital movement that is mostly concerned with the rise in the collapse of the overall financial market. It is difficult to prevent money laundering since it has a plausible sort of trade characterization. The aim of the paper is to develop monitoring methods that have accurate recognition along with classified form of supervision of the trade based money laundering with the help of multi class knowledge driven classification algorithms that are linked with the micro and macro prudential regulations. Based on an empirical study from China the application is reviewed and the effectiveness is assessed in order to improve the efficiency of the management in the financial markets (Chao, Kou, Peng, \& Alsaadi, 2019).

Selecting the most eligible customers for a loan is also essential to managing credit risk: a bank can screen through a list of customers to identify the ones who have a higher probability of repayment within the specified time duration, according to the terms and conditions of the contract. Hentschel and Kothari (1995) emphasized that using different derivatives is significant for the leverage of the financial institution. A vast majority of companies surveyed were using derivatives to reduce their risk (Kou, Peng, \& Wang, 2014). Dolde, (1993) highlighted that several banks are vulnerable to various risks, therefore, banks have undertaken specific precautionary measures like training their employees, developing better credit policies and reviewing the credit rating of the customers applying for the loans (Dolde, 1993).

Diversification is adopted by corporations for increasing the returns of the shareholders and minimizing risk. Decision-making criteria is improved by using classifiers that have some algorithms for resolving problems (Kou, Lu, Peng, \& Shi, 2012). Rumelt (1974) revealed that only around $14 \%$ of firms on the Fortune 500 list were working as single business organizations in 1974, whereas $86 \%$ of the businesses operated in diversified product markets. This shows a considerable inclination of the business sector to emphasize diversification instead of single trade. Much research has been conducted focusing on the activities of companies during recent times; most have found a rise in the prevalence of diversified firms (Datta et al., 1991).

\section{Research hypotheses}

The first hypothesis considers assessing the role of hedging in reducing a bank's credit. Based on a model presented by Felix (2008), which showed risk management strategies of hedging, capital adequacy ratio and diversification may be used to explain credit risk that a bank faces. Thus our first hypothesis is as follows:

\section{$\mathrm{H}_{1}$ : hedging will minimize credit risk faced by the commercial banks of Balochistan}

The second risk management strategy is diversification, which requires banks to provide a wide range of financial services with flexible terms to customers and to provide credit to a wide range of customers instead of few in order to reduce risk (Fredrick, 2013). The concept of diversification can be used by banks as they create a wide 
customer pool for providing loans, instead of providing large amount of loans to few customers, which inherently increases risk (Hobson, 1998). Therefore,

$\mathrm{H}_{2}$ diversification will minimize credit risk of the commercial banks of Balochistan

The third hypothesis considers management strategy that requires banks to maintain a particular amount of the capital (Ho \& Yusoff, 2009). The capital adequacy ratio is critical for banks to be in a better position to manage unexpected risks and thus capital maintained in a bank has a consequence at overall credit risk therefore the it may be hypothesized as following:

\section{$\mathrm{H}_{3}$ : capital adequacy ratio will minimize credit risk of commercial banks of Balochistan}

The fourth hypothesis considers the role played by corporate governance in minimizing credit risk. Corporate governance assumes that the organization or corporation should adopt all practices that ensure accountability to the stakeholders (Shafiq \& Nasr, 2010). Therefore,

\section{$\mathrm{H}_{4}$ : corporate governance will minimize credit risk of the commercial banks of Balochistan}

\section{Methodology}

This study adopts an explanatory research design, which was aimed to collect authentic, credible and unbiased data. The data were collected from the employees of commercial banks located in the province of Balochistan, Pakistan. All ethical considerations were made during the research process. The questionnaire developed for the collection of information was prepared to effectively incorporate all potential factors that include, diversification, hedging, capital adequacy ratio, corporate governance and credit risk. The purpose of this research was clearly explained in the questionnaire as it was being shared with the respondents.

The participants were informed about the research objective and ensured that the information provided would be kept confidential. This step was designed to remove bias and ensure that the participants were able to share their views without having any reservations. This process is important for authentic results and reliable information (Levitt, 2004).

The sample size for this study comprised of 250 employees from commercial banks in Balochistan. There are large scale commercial banks that operate in Pakistan with several branches of these banks working in the entire country. Commercial banks approached for this study included Habib Bank Limited, Standard Chartered Bank, United Bank Limited, Summit Bank, Faisal Bank, Askari Bank and Bank Al-Habib.

The questionnaire was adopted from a global survey previously conducted by the World Bank. This study analyzed the work that has been done on managing credit risk in several countries in different parts of the world. Our questionnaire used the framework of this valuable research tool, adopting changes specific to address the localized context of Balochistan.

The information collected from the participants was analyzed to identify trends and practices in the banks operating in Balochistan to understand the practices of these 
commercial banks for managing credit risk. Following is the theoretical framework of the study.

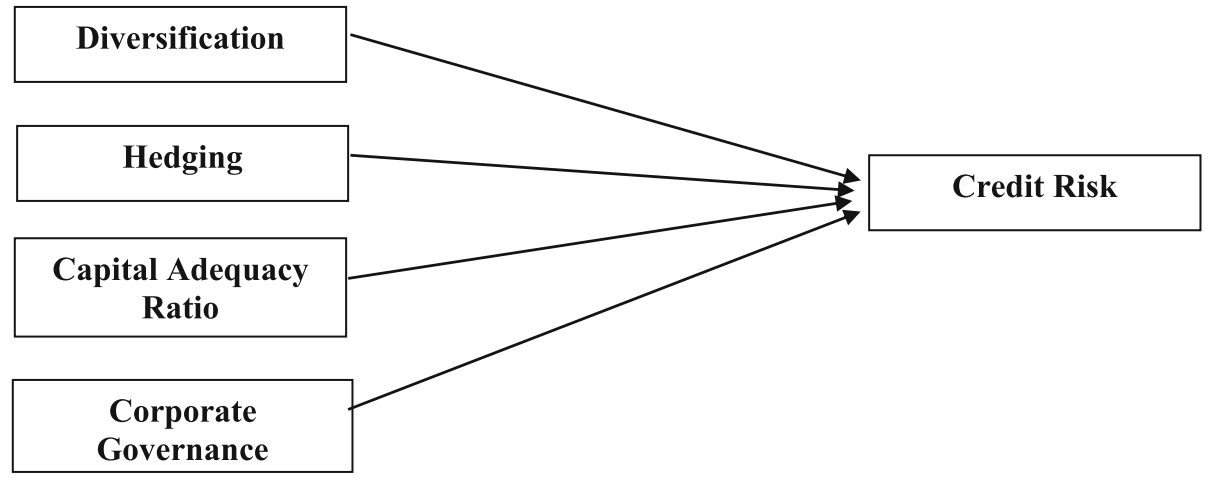

The relationships between risk management strategies such as diversification, hedging, the capital adequacy ratio and corporate governance with credit risk itself were determined in the paper.

\section{Results \& findings}

The questionnaire was tested to check the reliability through Cronbach's alpha (Table 1), which shows internal consistency of the instrument; the information revealed that the data are $80 \%$ reliable, considering the total of 31 questions asked. The information is essential as this shows that the results and findings of the study are reliable and they can be generalized to the population (Hungerford, 2005).

The correlation table shows the relationship between the different variables in the research study. The dependent variable, credit risk, was reviewed against the independent variables: corporate governance, hedging, diversification and capital adequacy ratio. The correlation is essential for further analysis as there should be some relation between the different variables. Each variable is used for the correlation analysis so it highlights the correlation among all the variables with each other. This is useful for assessing the correlation among the independent variables and to ensure that it is not too high leading to a problem of multicollinearity.

Table 2 shows the results of the correlation test between the independent variables and the dependent variable. Before running regression analysis, basic assumptions were also checked. Data normality was checked through skewness and kurtosis and for all variables; these values were in range \pm 2 . Linearity was checked through correlation analysis and all variables were shown to have a significant relationship with each other. Homogeneity was checked through scatter plot, showing that the variance across all variables was the same. No autocorrelation was found as the value for the Durbin Watson test was 2, showing no correlation among residuals (Antonakis, Bendahan, Jacquart, \& Lalive, 2014). The value for the variance inflation factor (VIF) was $\operatorname{VIF}<5$, which shows no relationship among the four independent variables. The regression test was

Table 1 Reliability Statistics

\begin{tabular}{lc}
\hline Cronbach's Alpha & N of Items \\
\hline 0.805 & 31 \\
\hline
\end{tabular}


Table 2 Correlations

\begin{tabular}{llllll}
\hline & Credit Risk & Corporate Governance & Hedging & Diversification & Capital Adequacy Ratio \\
\hline Credit Risk & 1 & & & & \\
Corporate Governance & $0.469^{* *}$ & 1 & & & \\
Hedging & $0.482^{* *}$ & $0.587^{* *}$ & 1 & & \\
Diversification & $0.355^{* *}$ & $0.078^{* *}$ & $0.207^{* *}$ & 1 & 1 \\
Capital Adequacy Ratio & $0.252^{* *}$ & $0.337^{* *}$ & $0.167^{* *}$ & $0.205^{* *}$ & \\
\hline
\end{tabular}

** Correlation is significant at the 0.01 level (2-tailed)

used to determine the influence of each of the variable on credit risk. The results can be seen in Table 3 .

Credit risk can be influenced by different factors but, there is around $36 \%$ influence of the four variables that are independent. The variation of $36 \%$ can be explained by the independent variables that are hedging, diversification, capital adequacy ratio and corporate governance on credit risk. These factors account for this much change that can be observed in the credit risk faced by the commercial banks. The adjusted $r^{2}$ was further analyzed because it is a better measure for a focused analysis on a bank's performance.

Table 4 shows the results of the assessment of the data for the overall model goodness of fit; the overall model is highly significant at $p<0.05$. The analysis of the variance across the small samples of the data reveals that the overall information is consistent.

The standardized coefficients in Table 5 show the rate of change that is caused by each of the variables in the credit risk of the commercial banks. This is critical information as the variable that is having a higher coefficient value will be having more influence on the level of credit risk so it should be emphasized more by the commercial banks for the sake of achieving better performance. The regression analysis highlights that the four independent variables have an impact on credit risk.

$$
\begin{aligned}
& \mathrm{CR}_{\mathrm{t}}=\alpha+\beta_{1} \mathrm{CG}+\beta_{2} \mathrm{DVF}+\beta_{3} \mathrm{HDG}+\beta_{4} \mathrm{CAR}+\mu \\
& \mathrm{CR}=1.765+0.288 \mathrm{CG}+0.263 \mathrm{DVF}+0.250 \mathrm{HDG}+0.040 \mathrm{CAR}+0.237
\end{aligned}
$$

The results reveal that corporate governance had the most impact on credit risk (with a 0.288 standardized beta value). In other words, this CRM strategy appears to be the most beneficial for commercial banks to undertake. Next is diversification ( 0.263 beta), followed by hedging ( 0.250 beta) and, finally, the capital adequacy ratio ( 0.040 beta). The results are significant in is showing that these variables have an impact on credit risk. The constant value was calculated at 1.765 and the error term in the equation is 0.237 .

Table 3 Model Summary

\begin{tabular}{lcccc}
\hline Model & $R$ & R Square & Adjusted R Square & Std. Error of the Estimate \\
\hline 1 & $0.601^{\text {a }}$ & 0.361 & 0.351 & 0.27789 \\
\hline $\begin{array}{l}\text { a. Predictors: (Constant), Capital Adequacy Ratio, Hedging, Diversification \& Corporate Governance } \\
\text { b. Dependent Variable: } \mathrm{CR}\end{array}$ &
\end{tabular}


Table 4 ANOVA $^{a}$

\begin{tabular}{lllcll}
\hline Model & Sum of Squares & df & Mean Square & $F$ & Sig. \\
\hline Regression & 10.699 & 4 & 2.675 & 34.636 & $0.000^{\mathrm{b}}$ \\
Residual & 18.920 & 245 & 0.077 & & \\
Total & 29.619 & 249 & & & \\
\hline
\end{tabular}

a. Dependent Variable: CR

b. Predictors: (Constant), CAR, HDG, DVF, CG

\section{Recommendations}

The banks in Balochistan would benefit from adopting sound strategies to improve control over credit risk. CRM strategies such as diversification, hedging, corporate governance and the capital adequacy ratio have all been cited in extant research as being crucial for the success in this regard; in fact, many problems arising from credit risk can be resolved by implementing some combination of these strategies. The research findings can likewise help the government of Balochistan to ensure that commercial banks take appropriate risk management measures to help keep them from failures, such as falling into bankruptcy (Greuning \& Bratanovic, 2009). Society depends on the smooth operation of the banking sector, so individual (and aggregate) bank performance can help contribute to the development and improved welfare of the economy. Therefore, effective inspection should be employed by the banks to check and safeguard bank resources. Effective trainings and refresher courses should be giving to bank employees in the areas of risk asset management, risk control and credit utilization in order to ensure proper usage and performance.

\section{Conclusion}

Several banks have failed in the past as they were not able to control their credit risk. Recommendations for banks stemming from this study include the diversification of their products and services, which is critical as it allows the bank to provide customers with many products and services. After diversification, an emphasis on employing corporate governance policies is most important, according to the findings. Hedging and the capital adequacy ratio are also important strategies that can be examined and optimized by banks. Hedging is useful because entering into flexible contracts helps reduce risk. The banks in Balochistan will be able to realize the importance of the capital adequacy ratio as that will allow them to achieve a proper balance between the amounts of capital that should be maintained to manage the needs of the investors. It is recommended that further research on the topic should be conducted so that effective strategies for management of other risks can be identified for banks. The success and

Table 5 Coefficients ${ }^{a}$

\begin{tabular}{lllll}
\hline & \multicolumn{2}{l}{ Standardized Coefficients } & $\mathrm{t}$ & Sig. \\
\cline { 2 - 3 } & $\mathrm{B}$ & \multicolumn{1}{c}{ Std. Error } & & \\
\hline (Constant) & 1.765 & 0.237 & 7.438 & .000 \\
Corporate Governance (CG) & 0.288 & 0.052 & 4.309 & 0.000 \\
Hedging (HDG) & 0.250 & 0.047 & 3.872 & 0.000 \\
Diversification (DVF) & 0.263 & 0.043 & 4.489 & 0.000 \\
Capital Adequacy Ratio (CAR) & 0.040 & 0.051 & 0.660 & 0.010 \\
\hline
\end{tabular}

a. Dependent Variable: Credit Risk (CR) 
further progress of these banks depend on the smooth implementation of risk management strategies and activities, which have been shown to have a very significant positive impact on the ability of the banks of Balochistan to control credit risk.

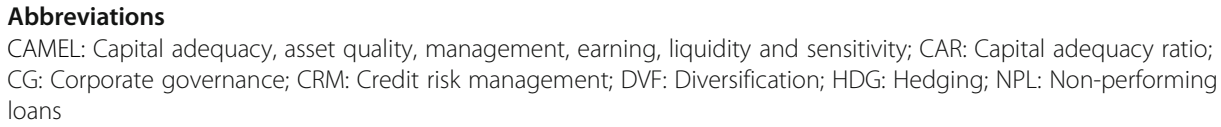

Acknowledgements

We are grateful to all the reviewers who have shared their valuable comments and suggestions for the research paper. The Editorial Board of Financial Innovation has been extremely kind in their editorial efforts.

\section{Authors contributions}

NM is the corresponding author and he has also given the idea for the paper. NM has reviewed the theoretical framework and empirical analysis of the research paper. ZR has written the manuscript and collected the data for the paper. BS has reviewed the methodology of the paper and reviewed literature. MAR has given conception advice and edited the paper. All authors have read the paper and approved the final manuscript.

\section{Funding}

There was no funding required for the completion of the research paper.

\section{Availability of data and materials}

The data of the research paper will be available upon request.

\section{Competing interests}

The authors declare that they have no competing interests.

Received: 6 February 2019 Accepted: 8 November 2019

Published online: 05 December 2019

\section{References}

Abiola I, Olausi AS (2014) The impact of credit risk management on the commercial banks performance in Nigeria. International Journal of Management and Sustainability 3(5):295-306

Al-Tamimi H (2008) Implementing Basel II: an investigation of the UAE banks' Basel II preparations. J Financ Regul Compliance 16(2):173-187

Andrews KR (1980) The concept of corporate strategy, Richard D. Irwin. Inc. Homewood. Illinois

Antonakis J, Bendahan S, Jacquart P, \& Lalive R (2014). Causality and endogeneity: Problems and solutions. New York: Oxford University Press.

Aruwa S, Musa AO (2014) Risk components and the financial performance of deposit money banks in Nigeria. Int J Soc Sci Entrepreneurship 1(11):514-522

Berríos MR (2013) The relationship between bank credit risk and profitability and liquidity. The Int J Bus Finance Res 7(3):105-118

Brown, Wang S (2002) Credit risk: the case of first interstate Bankcorp. Int Rev Financ Anal 11(2):229-248

Brown, Moles (eds) (2014) Credit risk management. Edinburgh, Edinburgh Business School, Heriot-Watt University

Campbell A (2007) Bank insolvency and the problem of nonperforming loans. J Bank Regul 9(1):25-45

Chao X, Kou G, Peng Y, Alsaadi FE (2019). Behavior monitoring methods for trade-based money laundering integrating macro and micro prudential regulation: a case from China. Technol Econ Dev Econ 25(6): 1081-1096

Datta DK, Rajagopalan N, Rasheed AMA (1991) Diversification and performance: critical review and future directions*. J Manag Stud 28(5):529-558. https://doi.org/10.1111/j.1467-6486.1991.tb00767.x

Dolde W (1993) Use of foreign exchange and interest rate risk management in large firms. Univ Conn Sch Bus Adm Working Pap:93-042

Dupire, B. (1992). Arbitrage pricing with stochastic volatility. Société Générale

Felix (2008) Bank performance and credit risk management: unpublished masters dissertation in finance. University of Skovde Skovde

Fredrick O (2013) The impact of credit risk management on financial performance of commercial banks in Kenya. DBA Afr Manage Rev 3(1)

Graham JR, Rogers DA (2002) Do firms hedge in response to tax incentives? J Financ 57(2):815-839

Greuning, \& Bratanovic. (2009) Analyzing Banking Risk A Framework for Assessing Corporate Governance and Financial Risk Washington D.C.: The World Bank

Hakim S, Neaime S (2005) Profitability and risk management in banking: a comparative analysis of Egypt and Lebanon Money and Finance in the Middle East: Missed Oportunities or Future Prospects? Vol. 6, pp. 117-131). Bingley: Emerald Group publishing limited

Harrison JM, Pliska SR (1981) Martingales and stochastic integrals in the theory of continuous trading. Stoch Process Appl 11(3):215-260

Heffernan S (1996) Современное банковское дело в теории и на практике (Modern Banking in Theory and Practice)

Hentschel L, Kothari S (1995) Life insurance or lottery: are corporations managing or taking risks with derivatives? Available at SSRN 6351

Ho CSF, Yusoff NI (2009) A Preliminary Study on Credit Risk Management Strategies of Selected Financial Institution in Malaysia. Jurnal Pengurusan(28), pp. 45-65

Hobson DG (1998) Robust hedging of the lookback option. Finance and Stochastics 2(4):329-347. 
Hungerford T (2005) Is financial risk adequately accounted for in social security reform measures? Issue Brief (Public Policy Institute (American Association of Retired Persons))(IB74), 1

Kargi HS (2011) Credit risk and the performance of Nigerian banks. Zaria, Ahmadu Bello University

Karoui N, Huang S (1997) A general result of existence and uniqueness of backward stochastic differential equations. In: Pitman Research Notes in Mathematics Series, pp 27-38

Keats BW (1990) Diversification and business economic performance revisited: issues of measurement and causality. J Manag 16(1):61-72

Kithinji AM (2010) Credit risk management and profitability of commercial banks in Kenya

Kolapo T, Ayeni R, Oke O (2012) Credit risk management and banks performance. Aust J Bus Manag Res 2(2):31-38

Kou, Chao X, Peng Y, Alsaadi FE, Herrera-Viedma E (2019) Machine learning methods for systemic risk analysis in financial sectors. Technol Econ Dev Econ:1-27

Kou Ergu D, Lin C, Chen Y (2016) Pairwise comparison matrix in multiple criteria decision making. Technol Econ Dev Econ 22(5):738-765

Kou, Lu Y, Peng Y, Shi Y (2012) Evaluation of classification algorithms using MCDM and rank correlation. Int J Inf Technol Decis Mak 11(01):197-225

Kou, Peng Y, Wang G (2014) Evaluation of clustering algorithms for financial risk analysis using MCDM methods. Inf Sci 275:1-12 Levitt J (2004) Transfer of financial risk and alternative financing solutions. J Health Care Finance 30(4):21-32

Li G, Kou G, Peng Y (2016) A group decision making model for integrating heterogeneous information. IEEE Trans on Syst, Man, and Cybern: Syst 48(6):982-992

Owojori AA, Akintoye IR, Adidu FA (2011) The challenge of risk management in Nigerian banks in the post consolidation era. J.Account Taxation 3(2):23-31

Poudel RPS (2012) The impact of credit risk management on financial performance of commercial banks in Nepal. Int J Arts Commerce 1(5):9-15

Reinhart CM, Rogoff KS (2008) Is the 2007 US sub-prime financial crisis so different? An international historical comparison. Am Econ Rev 98(2):339-344

Rumelt RP (1974) Strategy, structure, and economic performance

Shafiq A, Nasr M (2010) Risk management practices followed by the commercial banks in Pakistan. Int Rev Bus Res Pap 6(2) $308-325$

Stulz RM (1996) Rethinking risk management. J Appl Corp Finance 9(3):8-25

Van Greuning H, Brajovic Bratanovic S (2009) Analyzing Banking Risk A Framework for Assessing Corporate Governance and Financial Risk. The World Bank

Zhang H, Kou G, Peng Y (2019) Soft consensus cost models for group decision making and economic interpretations. Eur J Oper Res 277(3):964-980

\section{Publisher's Note}

Springer Nature remains neutral with regard to jurisdictional claims in published maps and institutional affiliations.

\section{Submit your manuscript to a SpringerOpen ${ }^{\circ}$ journal and benefit from:}

- Convenient online submission

- Rigorous peer review

- Open access: articles freely available online

High visibility within the field

- Retaining the copyright to your article

Submit your next manuscript at $\boldsymbol{\nabla}$ springeropen.com 